\title{
The Relationship Between the Long-Term Non- Rehabilitated Benign Paroxysmal Positional Vertigo and Vestibular Hypofunction
}

\author{
Uzun Süre Rehabilite Edilmemiş Benign Paroksismal Pozisyonel Vertigo ve \\ Vestibüler Hipofonksiyon Iliş̧kisi
}

\author{
๑ Dastan Temirbekov, ๑ Erdal Sakallı, ๑ Gamze Kıllıc * \\ Istanbul Aydin University Faculty of Medicine, Department of Otorhinolaryngology, Istanbul, Turkey \\ *Erdem Hospital, Clinic of Physical Therapy and Rehabilitation, Istanbul, Turkey
}

Abstract

\begin{abstract}
Aim: Recurrent Benign paroxysmal positional vertigo (BPPV) and vestibular hypofunction (VH) can be co-diagnosed in some patients. We aimed to sight the relationship between the recurrent BPPV and $\mathrm{VH}$, and to evaluate the change in the $\mathrm{VH}$ prevelance according to recurrent BPPV duration.
\end{abstract}

Methods: We conducted a retrospective chart review of 416 patients who were diagnosed with recurrent BPPV. Demographic features of the patients, co-diagnosis frequency of recurrent BPPV and $\mathrm{VH}$, and the change in the $\mathrm{VH}$ prevelance according to recurrent BPPV duration were recorded. Patients were divided into two groups for having BPPV attacks for more than 12 months or less than 12 months. Both groups were compared in terms of $\mathrm{VH}$ prevalence.

Results: VH was co-diagnosed in $61.7 \%$ of patients with BPPV. The age of the recurrent BPPV patients with $\mathrm{VH}$ was significantly higher than the patients without $\mathrm{VH}(p<0.05)$. $\mathrm{VH}$ positivity was directly correlated with the duration of recurrent BPPV. $\mathrm{VH}$ prevelance was significantly higher in the group that the BPPV duration was above 12 months than in the group that the recurrent BPPV duration was under 12 months $(p<0.05)$.

Conclusion: $\mathrm{VH}$ is common in patients with recurrent BPPV. There is may be a causal relationship between BPPV and $\mathrm{VH}$.

Keywords: Benign paroxysmal positional vertigo, peripheral vestibulopathy, vestibular hypofunction, BPPV, vestibulopathy
Amaç: Benign paroksismal pozisyonel vertigo (BPPV) ve vestibüler hipofonksiyon $(\mathrm{VH})$ bazı hastalarda birlikte görülebilir. Çalışmamızda, BPPV ve VH arasındaki ilişkiyi gözlemlemeyi ve tekrarlayan BPPV süresine göre VH görülme sıklı̆ındaki değişimi araştırmayı amaçladık.

Yöntemler: BPPV tanısı almış 416 hastanın geriye dönük dosya incelemesi yapıldı. Hastaların demografik özellikleri, BPPV ve VH birlikteliğindeki sıklık ve de BPPV süresine göre VH görülme sıklığındaki değişim kaydedildi. Hastalar 12 aydan daha uzun süredir tekrarlayan ve son 11 ay içinde gelişen ve/veya tekrarlayan BPPV'li olmak üzere iki gruba ayırıldı. Her iki gruptaki hastalar VH sıklığı açısından karşılaştıııldı.

Bulgular: BPPV'li hastaların \%61,7'sinde ayrıca VH tanısı konuldu. VH ile birlikte olan BPPV'li hastaların yaş ortalaması, $\mathrm{VH}$ ile birlikte olmayan BPPV'li hastaların yaş ortalamasına göre anlamlı olarak yüksekti $(P C 0,05)$. VH ile birlikte olan veya olmayan BPPV'li hastaların cinsiyet dağılımında anlamlı fark yoktu $(p<0,05)$. VH pozitifliği ile tekrarlayan BPPV süresi doğru orantılı idi. Tekrarlayan BPPV süresi 12 aydan uzun olan gruptaki VH sıklığı, BPPV süresi 12 aydan kısa olan gruba göre anlamlı olarak yüksekti $(p<0,05)$.

Sonuç: Uzun süredir tekrarlayan BPPV'li hastalarda VH görülmesi yaygındır. VH ile BPPV'nin bir sebep-sonuç ilişkisi olabilir.

Anahtar Sözcükler: Benign paroksismal pozisyonel vertigo, periferik vestibülopati, vestibüler hipofonksiyon, BPPV, vestibülopati
Address for Correspondence/Yazışma Adresi: Erdal Sakallı, İstanbul Aydin University Faculty of Medicine, Department of Otorhinolaryngology, istanbul, Turkey Phone: +90 5334417710 E-mail: erdalkbb1979@hotmail.com ORCID: orcid.org/0000-0003-1582-1816 Received/Geliş Tarihi: 29.07.2020 Accepted/Kabul Tarihi: 12.11.2020
${ }^{\circ}$ Copyright 2021 by The Medical Bulletin of istanbul Haseki Training and Research Hospital The Medical Bulletin of Haseki published by Galenos Yayınevi. ${ }^{\bullet}$ Telif Hakkı 2021 istanbul Haseki Eğitim ve Araştırma Hastanesi Haseki Tıp Bülteni, Galenos Yayınevi tarafindan yayınlanmıştı. 


\section{Introduction}

Peripheral vestibular dysfunction is one of the most common reasons for applying to the hospitals. The most common cause of peripheral vestibular dysfunction is benign paroxysmal positional vertigo (BPPV) (1). BPPV is characterized by short (seconds to minutes) recurrent episodes of positional vertigo and dizziness provoked by changes in head position. Displaced otoconia (canalolithiasis or cupulolithiasis) are thought to cause BPPV by mechanically stimulating the vestibular receptors within the semicircular canals $(2,3)$.

The second most common cause of peripheral vestibular dysfunction is vestibular hypofunction (VH), which can be described as a disturbance of the vestibuloocular reflex (VOR) in one or both of the inner ears (4). The VOR assists in maintaining gaze stability, which allows the eyes to maintain focus on a target while the head is moving. As the VOR is disturbed in $\mathrm{VH}$, tracking of moving objects becomes difficult, which is an important symptom of $\mathrm{VH}(1,5)$.

Among patients with BPPV or VH who have not undergone appropriate medical treatment, intentional movement restriction and hypodynamics are often experienced due to fear of falling (6). Previous studies have shown that leading a sedentary lifestyle and hypodynamics have negative effects on the balance system, while sports and movement have positive effects on it $(7,8)$. In our clinical experiences, we often observe $\mathrm{VH}$ symptoms in BPPV patients even after successful canalith repositioning. Thus, we speculated that prolonged movement restriction may cause secondary $\mathrm{VH}$.

We aimed to investigate the frequency of co-diagnosis of BPPV and VH and also to find the relationship between the $\mathrm{VH}$ prevelance and recurrent BPPV duration.

\section{Methods}

Patients who were admitted to our audio-vestibular center between January 2016 and January 2020 and underwent detailed vestibular examination were recruited for this study. The study protocol was approved by the Ethics Committee of istanbul Aydın University, Faculty of Medicine (number: 2020/240). Patients between 18 and 65 years of age who were diagnosed with BPPV were included in the study. The diagnosis of BPPV was made according to the 2015 Barany Society criteria (9). The onset of dizziness of every subject was determined by examining the history of the selected patients. The patients were divided into two groups depending on for how long the recurrent BPPV had been troubling, as less than 12 months (control group) and 12 months or more (study group). The both groups patients were investigated in terms of $\mathrm{VH}$. During the evaluation of $\mathrm{VH}$, the Dizziness
Handicap Inventory Questionnaire (validated Turkish version) was completed by patients according to their anamnesis (10). Videonystagmography (VNG) recorded vestibular examination, including saccade test, tracking test, optokinetic test, gaze test, Dix-Halpike maneuver, air-stimulated binaural bithermal caloric test, fixation suppression test, baseline shift, gain asymmetry were taken into consideration. VNG equipment from Otometrics (ICS Chartr 200; Taastrup, Denmark) and a computerized system were used for VH diagnosis. PC-VNG software was used for automatic analysis of the recordings. The following criterias were used to diagnose $\mathrm{VH}$.

A. Chronic vestibular syndrome with the following symptoms:

1. Unsteadiness when walking or standing plus at least one of 2 or 3.

2. Movement-induced blurred vision or oscillopsia during walking or quick head/body movements and/or.

3. Worsening of unsteadiness in darkness and/or on uneven ground.

B. No symptoms while sitting or lying down under static conditions

C. Bilateral weakness in the caloric response was considered based on the 2017 Barany Society criteria (11): Bilaterally reduced or absent angular VOR function documented by reduced caloric response (sum of bithermal maximum peak Slow-phase velocity on each side $<6 \circ / \mathrm{sec}$ ).

D. Unilateral weakness in the caloric response was quantified according to the Jongkees formula. A value greater than or equal to $25 \%$ was pathological according to our normative data. Additionally, the directional preponderance (DP) was measured using the formula $D P=[(R W+L C)-(L W+R C)] /(R W+L W+R C+L C) \times 100$. Normal absolute values in our lab are below a DP of $30 \%$.

E. Not better accounted for by another disease

The both groups patients were statistically compared in terms of $\mathrm{VH}$ frequency. The demographic characteristics of the patients, relationship between BPPV duration and $\mathrm{VH}$ prevelance, involved semicircular canal, and involved ear were investigated and analyzed.

Patients with any additional otologic pathologies that can cause $\mathrm{VH}$ (including endolymphatic hydrops, history of labyrinthitis, vestibular neurinitis, trauma, and meningitis), patients with additional neurologic or orthopedic pathologies, patients less than 18 or more than 65 years of age, patients with incomplete anamnesis and/ or questionnaire, and patients who had not undergone VNG recorded vestibular examination were excluded from the study. Patients whose anamnesis suggested that $\mathrm{VH}$ developed before BPPV occurred were also excluded from the study. 


\section{Statistical Analysis}

Mean, standard deviation, median, lowest and highest frequency, and ratio values were used as descriptive statistics of the data. The distribution of variables was measured using the Kolmogorov-Smirnov test. In the analysis of quantitative independent data, the MannWhitney $\mathrm{U}$ test was used. The chi-square test was used for the analysis of qualitative independent data. The Statistical Package for the Social Sciences (SPSS) 22.0 program was used in the analysis.

\section{Results}

Of the 416 patients diagnosed with BPPV who matched our study criteria, 257 (61.7\%) had VH, and 159 (38.2\%) did not have $\mathrm{VH}$. The demographic features and VNG records of the BPPV patients are shown in Table 1. The age of the patients with $\mathrm{VH}$ was significantly higher than the age of the patients without $\mathrm{VH}(\mathrm{p}<0.05)$. There was no significant difference in gender distribution between the BPPV patients with and without $\mathrm{VH}(p<0.05)$. There was no significant difference between the groups in terms of saccade positivity, gaze positivity, tracking test positivity, and optokinetic test positivity ( $p>0.05)$ (Table 2). In the patients with $\mathrm{VH}$, the duration of the BPPV was significantly longer than in the patients without $\mathrm{VH}$ $(p<0.05)$ (Figure 1). We found that the duration of BPPV was directly correlated with VH positivity (Figure 2). In the study group (BPPV duration $\geq 12$ month), $\mathrm{VH}$ positivity was significantly higher than in the control group (BPPV duration $<12$ month) $(p<0.05)$ (Figure 3$)$. The age of the patients with bilateral $\mathrm{VH}$ was significantly higher than the age of the patients with unilateral $\mathrm{VH}(\mathrm{p}<0.05)$. There were no statistically significant differences in patients with bilateral or unilateral $\mathrm{VH}(\mathrm{p}<0.05)$ in terms of gender distribution, duration of BPPV, and optokinetic test results (Table 3).

\section{Discussion}

BPPV has been shown to be related with otologic disorders, including sudden idiopathic hearing loss, vestibular neuritis, and Meniere's disease (12-14). BPPV may develop after head trauma or inner ear surgery (stapes surgery, cochlear implantation, or when repairing superior canal dehiscence) (15). Patients with an acute

\begin{tabular}{|c|c|c|c|c|c|c|c|c|}
\hline & & Min & & & Median & Mean & & \\
\hline \multicolumn{2}{|l|}{ Age (years) } & 7.0 & - & 91.0 & 50.0 & 49.0 & \pm & 16.0 \\
\hline \multirow{2}{*}{ Sex } & Female & & & & & 280 & & $67.5 \%$ \\
\hline & Male & & & & & 136 & & $32.8 \%$ \\
\hline \multicolumn{2}{|l|}{ BPPV time (months) } & 0.1 & - & 420.0 & 5.3 & 30.7 & \pm & 60.8 \\
\hline \multirow{2}{*}{ Saccade } & $(-)$ & & & & & 383 & & $92.3 \%$ \\
\hline & $(+)$ & & & & & 33 & & $8.0 \%$ \\
\hline \multirow{2}{*}{ Gaze } & $(-)$ & & & & & 416 & & $100.2 \%$ \\
\hline & $(+)$ & & & & & 0 & & $0.0 \%$ \\
\hline \multirow{2}{*}{ Tracking } & $(-)$ & & & & & 298 & & $71.8 \%$ \\
\hline & $(+)$ & & & & & 118 & & $28.4 \%$ \\
\hline \multirow{2}{*}{ Optokinetic } & $(-)$ & & & & & 299 & & $72.0 \%$ \\
\hline & $(+)$ & & & & & 117 & & $28.2 \%$ \\
\hline \multirow{2}{*}{ ROLL test } & $(-)$ & & & & & 389 & & $93.7 \%$ \\
\hline & $(+)$ & & & & & 27 & & $6.5 \%$ \\
\hline \multirow{2}{*}{ DIX hallpike right } & $(-)$ & & & & & 123 & & $29.6 \%$ \\
\hline & $(+)$ & & & & & 293 & & $70.6 \%$ \\
\hline \multirow{2}{*}{ DIX hallpike left } & $(-)$ & & & & & 136 & & $32.8 \%$ \\
\hline & $(+)$ & & & & & 280 & & $67.5 \%$ \\
\hline \multirow{2}{*}{ Vestibular hypofunction } & $(-)$ & & & & & 159 & & $38.3 \%$ \\
\hline & $(+)$ & & & & & 257 & & $61.9 \%$ \\
\hline- & Right & & & & & 107 & & $25.8 \%$ \\
\hline- & Left & & & & & 101 & & $24.3 \%$ \\
\hline- & Bilateral & & & & & 49 & & $11.8 \%$ \\
\hline
\end{tabular}


Table 2. Comparison of the patients regarding BPPV duration and VH positivity

\begin{tabular}{|c|c|c|c|c|c|c|c|c|c|c|c|}
\hline \multirow[b]{3}{*}{ Age (years) } & & \multicolumn{4}{|c|}{ Vestibular Hypofunction (-) } & \multicolumn{4}{|c|}{ Vestibular Hypofunction (+) } & \multirow{2}{*}{\multicolumn{2}{|c|}{$p$}} \\
\hline & & \multicolumn{3}{|c|}{ Mean $\pm \mathrm{SD} / \mathrm{n}-\%$} & \multirow{2}{*}{$\begin{array}{l}\text { Median } \\
47.5\end{array}$} & \multicolumn{3}{|c|}{ Mean $\pm \mathrm{SD} / \mathrm{n}-\%$} & \multirow{2}{*}{\begin{tabular}{|l} 
Median \\
51.0
\end{tabular}} & & \\
\hline & & 46.3 & \pm & 16.5 & & 50.6 & \pm & 15.4 & & 0.015 & $\mathrm{~m}$ \\
\hline \multirow{2}{*}{ Sex } & Female & 110 & & $69.2 \%$ & & 170 & & $66.1 \%$ & & \multirow{2}{*}{0.521} & \multirow{2}{*}{$x^{2}$} \\
\hline & Male & 49 & & $30.8 \%$ & & 87 & & $33.9 \%$ & & & \\
\hline \multicolumn{2}{|l|}{ BPPV time (months) } & 17.7 & \pm & 43.9 & 1.0 & 38.8 & \pm & 68.1 & 12.0 & 0.000 & $\mathrm{~m}$ \\
\hline BPPV time (monhts) & $\leq 12>12$ & $\begin{array}{l}120 \\
39\end{array}$ & & $\begin{array}{l}75.5 \% \\
24.5 \% \\
\end{array}$ & 1.0 & $\begin{array}{l}139 \\
118 \\
\end{array}$ & & $\begin{array}{l}54.1 \% \\
45.9 \% \\
\end{array}$ & & 0.000 & $x^{2}$ \\
\hline BPPV & $(-)(+)$ & \begin{tabular}{|l|}
0 \\
159 \\
\end{tabular} & & \begin{tabular}{|l|}
$0 \%$ \\
$100 \%$ \\
\end{tabular} & & \begin{tabular}{|l|} 
\\
257 \\
\end{tabular} & & \begin{tabular}{|l|}
$0.0 \%$ \\
$100 \%$ \\
\end{tabular} & & 1.000 & $x^{2}$ \\
\hline \multirow{2}{*}{ Saccade } & $(-)$ & 148 & & $93.1 \%$ & & 235 & & $91.4 \%$ & & \multirow{2}{*}{0.547} & \multirow{2}{*}{$x^{2}$} \\
\hline & $(+)$ & 11 & & $6.9 \%$ & & 22 & & $8.6 \%$ & & & \\
\hline \multirow{2}{*}{ Gaze } & $(-)$ & 159 & & $100.0 \%$ & & 257 & & $100.0 \%$ & & \multirow{2}{*}{1.000} & \multirow{2}{*}{$x^{2}$} \\
\hline & $(+)$ & 0 & & $0.0 \%$ & & 0 & & $0.0 \%$ & & & \\
\hline \multirow{2}{*}{ Tracking } & $(-)$ & 114 & & $71.7 \%$ & & 184 & & $71.6 \%$ & & \multirow{2}{*}{0.982} & \multirow{2}{*}{$x^{2}$} \\
\hline & $(+)$ & 45 & & $28.3 \%$ & & 73 & & $28.4 \%$ & & & \\
\hline \multirow{2}{*}{ Optokinetic } & $(-)$ & 115 & & $72.3 \%$ & & 184 & & $71.6 \%$ & & \multirow{2}{*}{0.872} & \multirow{2}{*}{$x^{2}$} \\
\hline & $(+)$ & 44 & & $27.7 \%$ & & 73 & & $28.4 \%$ & & & \\
\hline \multirow{2}{*}{ ROLL test } & $(-)$ & 146 & & $91.8 \%$ & & 243 & & $94.6 \%$ & & \multirow{2}{*}{0.272} & \multirow{2}{*}{$x^{2}$} \\
\hline & $(+)$ & 13 & & $8,2 \%$ & & 14 & & $5,4 \%$ & & & \\
\hline \multirow{2}{*}{ DIX hallpike right } & $(-)$ & 55 & & $34.6 \%$ & & 68 & & $26.5 \%$ & & \multirow{2}{*}{0.077} & \multirow{2}{*}{$x^{2}$} \\
\hline & $(+)$ & 104 & & $65.4 \%$ & & 189 & & $73.5 \%$ & & & \\
\hline \multirow{2}{*}{ DIX hallpike left } & $(-)$ & 60 & & $37.7 \%$ & & 76 & & $29.6 \%$ & & \multirow{2}{*}{0.085} & \\
\hline & $(+)$ & 99 & & $62.3 \%$ & & 181 & & $70.4 \%$ & & & $x^{2}$ \\
\hline
\end{tabular}

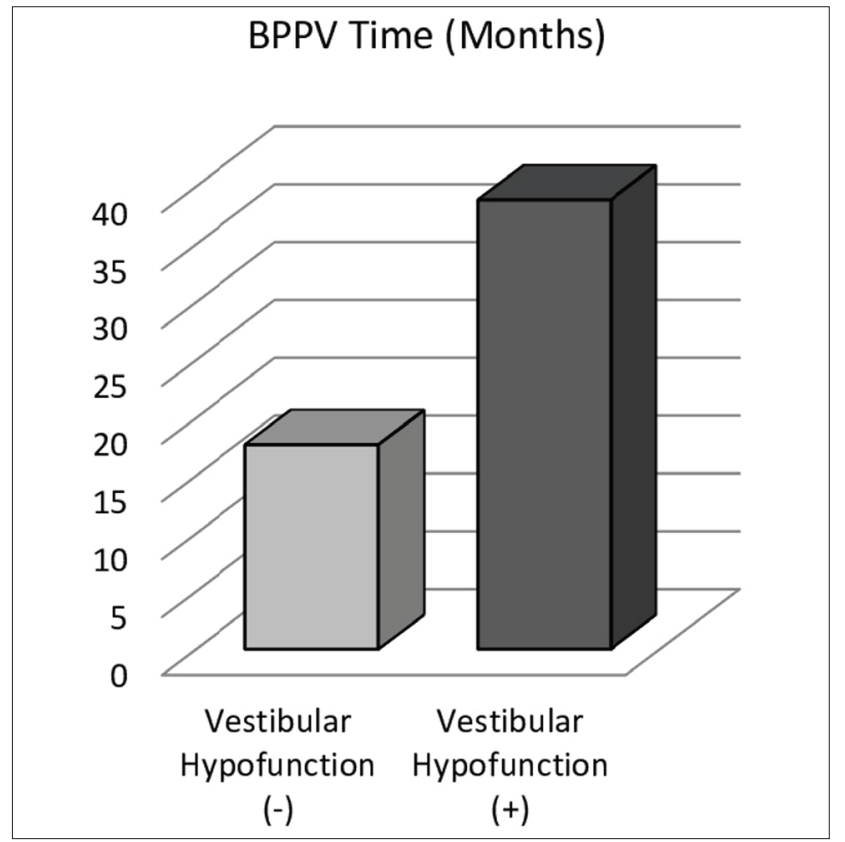

Figure 1. The duration of BPPV between the patients with and without vestibular hypofunction $B P P V$ : Benign paroxysmal positional vertigo

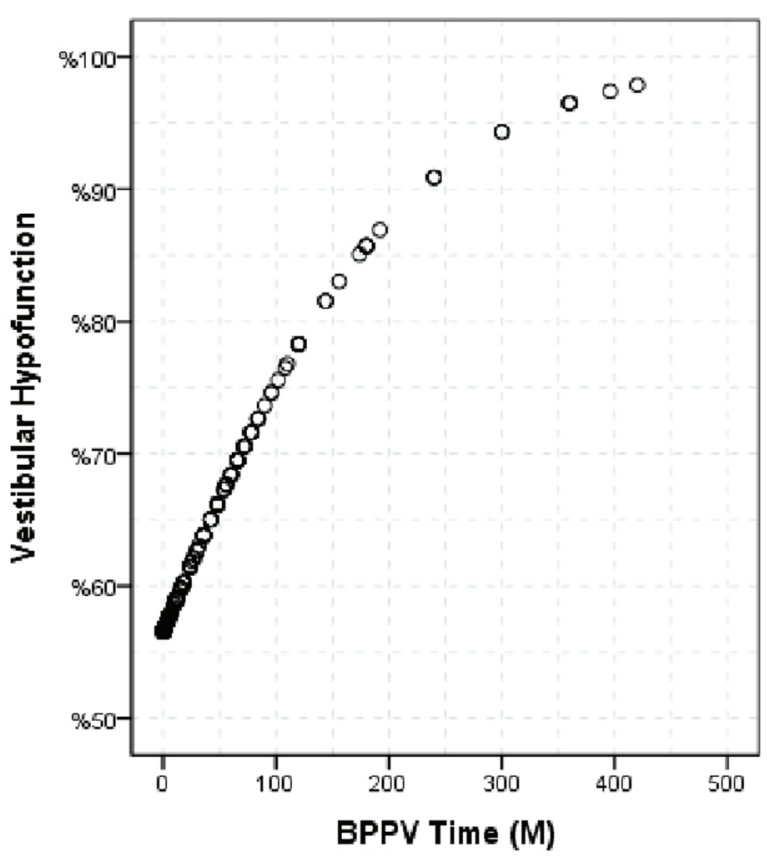

Figure 2. The correlation between duration of BPPV and $\mathrm{VH}$ BPPV: Benign paroxysmal positional vertigo, VH: Vestibular hypofunction 
and/or chronic unilateral peripheral vestibulopathy can develop recurrent posterior canal BPPV in the same ear $(16,17)$.

In a recent study, it was reported that patients with a history of BPPV and otologic disease were more likely to have $\mathrm{VH}$ than those without a history of otologic disease (18). However, the relationship between VH and BPPV has not been comprehensively described in the literature. There is only one study, conducted by Summer et al. (19) in 2012, in which the rate of co-diagnosis of VH and BPPV,

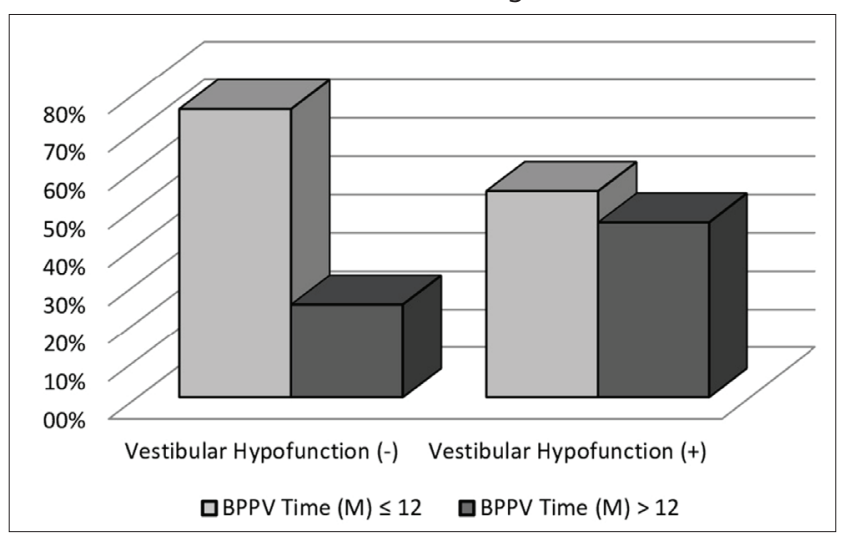

Figure 3. Comparison of vestibular hypofunction prevelance between the patients who have BPPV more than 12 months and less than 12 months

BPPV: Benign paroxysmal positional vertigo the frequency of admission to physical therapy, and the relationship with patients' ages were determined. They retrospectively reviewed 500 medical records of patients diagnosed with VNG. They found that 38\% of their patients had a single diagnosis, and $6.6 \%$ of their patients had a co-diagnosis. They also found a positive relationship between VH-BPPV co-diagnosis and increased age. We also found significantly higher ages in BPPV patients with VH than in patients without VH (19). However, it is possible that the increase in co-diagnosis with age may simply be due to the increased incidence of both $\mathrm{VH}$ and BPPV in the elderly.

Physical activity including head and body movements is important factor for recovering from vestibular dysfunctions. On the other hand, prolonged dizziness caused by vestibulopathies including BPPV is a risk factor for developing anxiety (20). Therefore, patients with untreated BPPV tend to be less active as a result of balance problems and anxiety $(6,20)$. Morimoto et al. (6) reported a study in which they provided objective measures of physical activity in patients with chronic unilateral vestibular hypofunction. They found direct correlation between physical activity and postural stability (6).

In the study by Summer M. and San Lucas (19), they did not determine the time course of $\mathrm{VH}$ and BPPV. It is possible that patients may have had $\mathrm{VH}$ years prior to VNG testing and developed BPPV near the time of VNG testing.

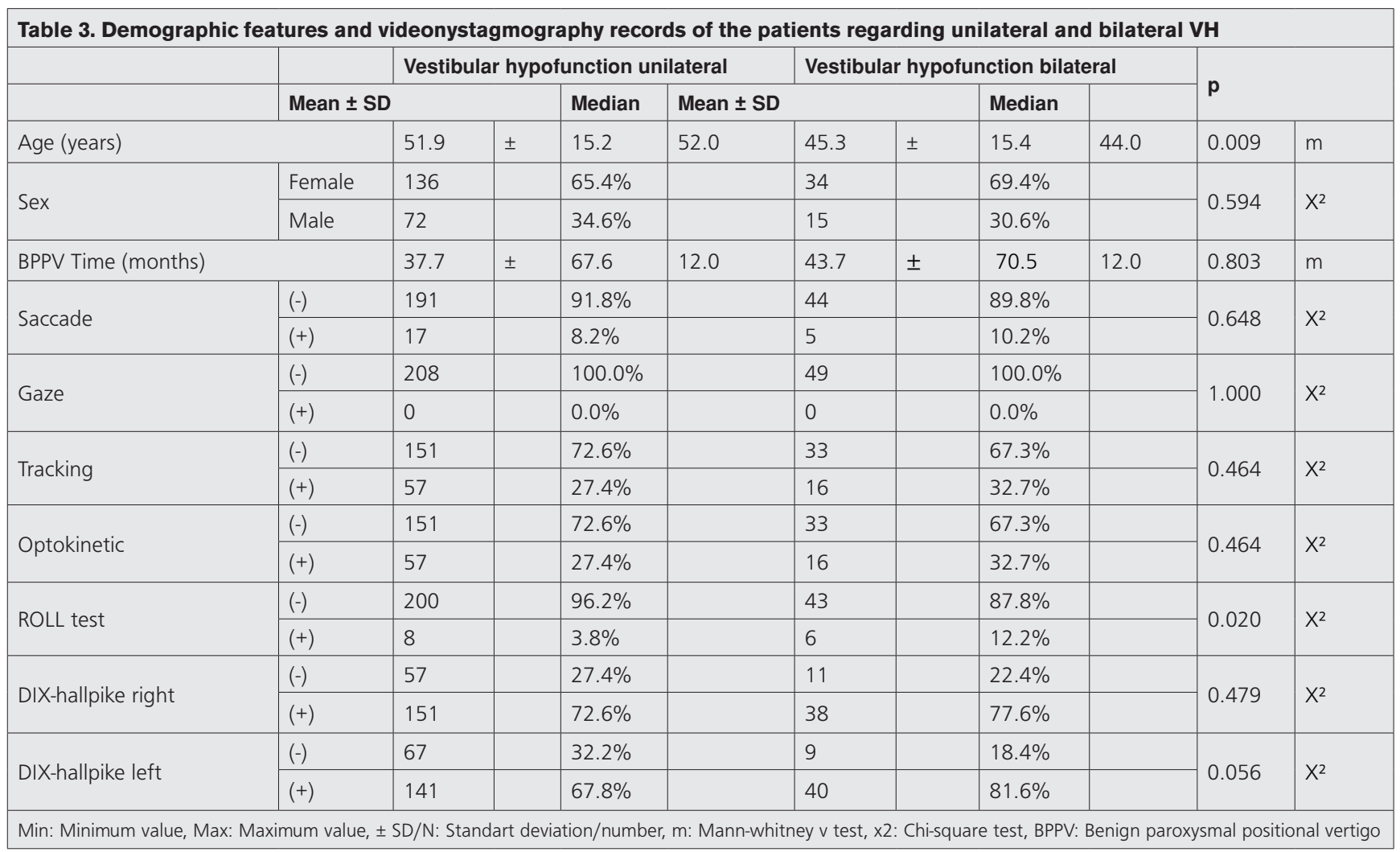


In our study, we recruited only BPPV patients. Out of the 416 BPPV patients, 257 (61.7\%) had VH, and 159 (38.2\%) did not have $\mathrm{VH}$. These remarkably different results may be due to the fact that our clinic is a referral center, and specific patients are admitted oftenly. For the same reason, we have had many BPPV cases that have not been treated for a long time.

We analyzed the correlation between the duration of recurrent BPPV and the frequency of $\mathrm{VH}$ in order to investigate the duration of recurrent BPPV as a risk factor for $\mathrm{VH}$. It was remarkable that we found a positive correlation. Since our audio-vestibular center is a tertiary center, we noted that most of our patients had previous examinations and treatments in other clinics and had not benefited or had recurrences. Thus, we excluded patients when it was revealed that they had developed $\mathrm{VH}$ before BPPV. However, this exclusion was provided based on the patients' history. Conversely, Summer M. and San Lucas (19), reported that they found a significant association between peripheral vestibular dysfunction and nonreferral to physical therapy after BPPV treatment. This data suggests that non-rehabilitated BPPV may contribute to the occurrence of $\mathrm{VH}$.

In order to distinguish long- and short-term BPPV, we chose a relative period of 12 months. Statistical analysis could not prove its usefulness as a cut-off time. If a patient has multiple sources of dizziness and only one source is treated, it is likely that the treatment will be incomplete. Accurate identification of BPPV and VH comorbidities will provide an appropriate treatment strategy. In cases of codiagnosis of BPPV and $\mathrm{VH}$, it is recommended that BPPV, which can be resolved in one to three sessions, be treated first (21). Then, rehabilitation procedures can be initiated to treat $\mathrm{VH}$.

The mean age of patients with $\mathrm{VH}$ was found to be significantly higher compared to those without $\mathrm{VH}$ (Table 2). It is known that vestibular response decreases with increasing age and old age is a risk factor for $\mathrm{VH}$. But, considering the follow-up periods of our patients, the average age of the group with $\mathrm{VH}$ is 50 years, the average follow-up period is 38 months (three years), while the average age of those without $\mathrm{VH}$ is 46 years and the average follow-up period is 17 months (1 year). In other words, we see that the ages at which the first BPPV attack developed in both groups are close to each other. Therefore, although there appears to be a statistical age difference between the patient group with $\mathrm{VH}$ and the group without $\mathrm{VH}$, we believe that this did not affect negatively our study results.

In conclusion, $\mathrm{VH}$, which is very common in the elderly population, quite often diagnosed together with BPPV.
Further investigations are needed regarding possible causal relationship of these conditions. We speculate that VH can develop because of prolonged movement restriction due to fear of falling. From this point of view early rehabilitation of BPPV can prevent VH development.

\section{Authorship Contributions}

Concept: D.T., Design: D.T., Data Collection or Processing: G.K., Analysis or Interpretation: E.S., Literature Search: D.T., E.S., Writing: E.S

Conflict of Interest: There is not any financial and personal relationships with other people or organisations. Also there is not any funding source.

Informed Consent: Consent form was filled out by all participants.

Financial Disclosure: The authors declared that this study received no financial support.

\section{References}

1. Sakalli E, Temirbekov D, Celikyurt C, Kılıç G, Practical diagnosis and management of peripheral vertigo. Praxis of Otorhinolaryngology 2017;5:57-62.

2. Mandalà M, Salerni L, Nuti D. Benign Positional Paroxysmal Vertigo Treatment: a Practical Update. Curr Treat Options Neurol 2019;21:66.

3. Nuti $\mathrm{D}$, Masini $M$, Mandalà $M$. Benign paroxysmal positional vertigo and its variants. Handb Clin Neurol 2016;137:241-56.

4. Walther LE. Current diagnostic procedures for diagnosing vertigo and dizziness. GMS Curr Top Otorhinolaryngol Head Neck Surg 2017;16:Doc02.

5. Uffer DS, Hegemann SC. About the pathophysiology of acute unilateral vestibular deficit - vestibular neuritis (VN) or peripheral vestibulopathy (PVP)? J Vestib Res 2016;26:311-7.

6. Morimoto $H$, Asai $Y$, Johnson EG, et al. Objective measures of physical activity in patients with chronic unilateral vestibular hypofunction, and its relationship to handicap, anxiety and postural stability. Auris Nasus Larynx 2019;46:70-7.

7. Krasnoff J, Painter P. The physiological consequences of bed rest and inactivity. Adv Ren Replace Ther 1999;6:124-32.

8. Leong HT, Fu SN, Ng GY, Tsang WW. Low-level Taekwondo practitioners have better somatosensory organisation in standing balance than sedentary people. Eur J Appl Physiol 2011;111:1787-93.

9. von Brevern $M$, Bertholon $P_{\text {, Brandt }} T$, et al. Benign paroxysmal positional vertigo: Diagnostic criteria. J Vestib Res 2015;25:105-17.

10. Canbal M, Cebeci S, Duyan GÇ, Kurtaran H, Arslan i. A study of reliability and validity for the Turkish version of dizziness handicap inventory. Turk. J. Family Med. Prim. Care 2016;10:19-24.

11. Strupp M, Kim JS, Murofushi T, et al. Bilateral vestibulopathy: Diagnostic criteria Consensus document of the Classification 
Committee of the Bárány Society. J Vestib Res 2017;27:17789.

12. Balatsouras DG, Ganelis P, Aspris A, Economou NC, Moukos A, Koukoutsis $\mathrm{G}$. Benign paroxysmal positional vertigo associated with Meniere's disease: epidemiological, pathophysiologic, clinical, and therapeutic aspects. Ann Otol Rhinol Laryngol 2012;121:682-8.

13. Kim MB, Ban JH. Benign paroxysmal positional vertigo accompanied by sudden sensorineural hearing loss: a comparative study with idiopathic benign paroxysmal positional vertigo. Laryngoscope 2012;122:2832-6.

14. Türk B, Akpinar M, Kaya KS, Korkut AY, Turgut S. Benign Paroxysmal Positional Vertigo: Comparison of Idiopathic BPPV and BPPV Secondary to Vestibular Neuritis. Ear Nose Throat J 2019. DOI: 10.1177/0145561319871234

15. Kao WT, Parnes LS, Chole RA. Otoconia and otolithic membrane fragments within the posterior semicircular canal in benign paroxysmal positional vertigo. Laryngoscope 2017;127:709-14.
16. Karlberg M, Hall K, Quickert N, Hinson J, Halmagyi GM. What inner ear diseases cause benign paroxysmal positional vertigo? Acta Otolaryngol 2000;120:380-5.

17. Meghji S, Murphy D, Nunney I, Phillips JS. The Seasonal Variation of Benign Paroxysmal Positional Vertigo. Otol Neurotol 2017;38:1315-8.

18. Sloane $P$, Blazer $D$, George LK. Dizziness in a community elderly population. J Am Geriatr Soc 1989;37:101-8.

19. Summer M, San Lucas. Co-diagnosis frequency of peripheral vestibular disorders and physical therapy. Loma Linda University Electronic Theses, Dissertations \& Projects.97. 2012.

20. Azevedo Da Silva M, Singh-Manoux A, Brunner EJ, Kaffashian S, Shipley MJ, Kivimäki M, et al. Bidirectional association between physical activity and symptoms of anxiety and depression: the Whitehall II study. Eur J Epidemiol 2012;27:537-46.

21. Herdman SJ. Canalith repositioning maneuver. Otolaryngol Head Neck Surg 1994;111:691-2. 